\title{
THE CONNECTION BETWEEN YOUR EMPLOYEES AND CUSTOMERS
}

\author{
Dr. K. R. Subramanian ${ }^{1 *}$ \\ ${ }^{* 1}$ Professor of Management \& Senior, Consultant-Operations, Credait.com
}

*Corresponding Author: -

\begin{abstract}
: -
As a business, you strive for acquiring and retaining happy customers. However, many businesses do not realize that the process starts with their employees and their job satisfaction with the company. This is one of the most undervalued aspects of developing a durable customer base. The employees want to feel the same way as their customers in their relationship with the company as everyone wants to feel appreciated. One of the negative impacts of modern technology is that many goods and services are turned into commodities. The quality of the service your employees provide is of paramount importance and this happens when employees are fully engaged. Connected employees are the employees who provide great customer service and a unique experience. Such cumulative experiences have progressively become the predominant motivation for customers to buy. Customers need to receive excellent products and services in order to spend their hard earned bucks. Of course yes, it is employees who will provide them this exceptional product or service. If the employees are miserable in their jobs this affects morale, innovation, and customer relationships and which does not translate into a great product and/or service. This is the connection between employees and customers.
\end{abstract}

Key words: - Customer retention and employee motivation, relationship with company, digitally connected employees and customers, excellent service, customer delight and company growth.

\section{(a) $(\$)$}




\section{INTRODUCTION}

Whenever there is a discussion about a new product or how to market it within the corporate confines of a company, there is a marketing myopia which is not understood in the right perspective in the light of the current environment of digital media proliferation. This will be explained in the following paragraphs. Marketing plans to sell the products to various customers through various channels after estimating the market potential and customer needs. The broader question is the need to understand the market segments and what the company aims to exploit. Often it is forgotten that the employees of the marketing company may also be part of the customer segment. To make this understanding clear let us take the example of a consumer Product Company in the business of bath soaps. The company products may be used by the employees along with their friends and relatives. So, the company is virtually a producer and consumer concurrently. What it implies is that the consumer response to the product will have an impact on the company employees. So, the company will have to foresee the eventuality of an unfavorable feedback from its own employees for what they produce and sell. The company response to such situations will be the testing ground for future of the product and marketing actions. If the companies are well managed, customer oriented and market sensitive there is less to worry about. Otherwise, there is too much to consider.

\section{Performance-Happiness Matrix}

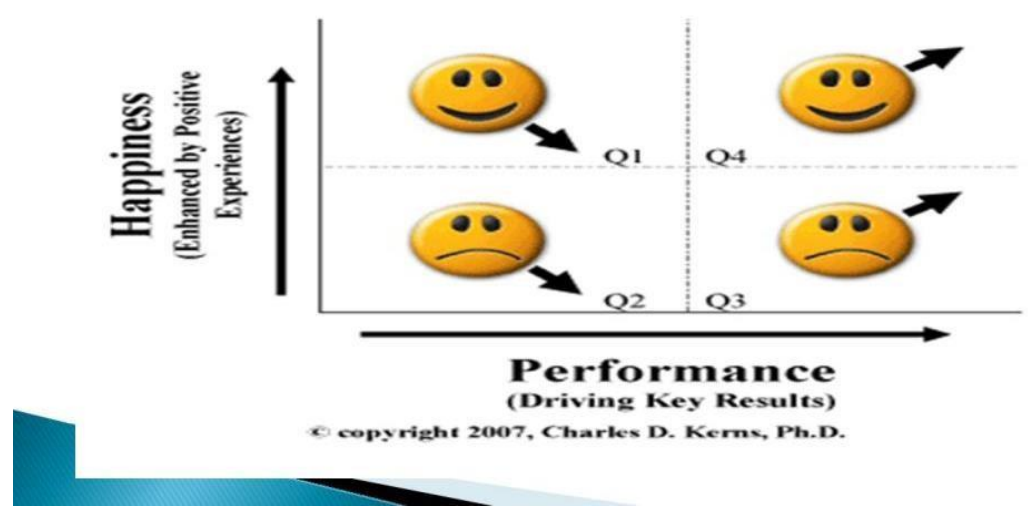

Figure 1: Happiness reflects on Employee Performance

Happy employees tend to exhibit their enthusiasm when interacting with customers. How employees are treated, or the atmosphere of the internal culture, will dictate how your employees feel. Attitude is tied to an employee's performance and is transformed into the quality of their work. Ultimately what is felt and experienced by customers through employees, turns into a decision to return to your business or visit a competitor (assuming there is nothing wrong with the product itself and your business is not the only business selling a particular product). When a company does not have to tell its customers why they are the best in their market, then it is naturally a business we gravitate to because we feel good about paying the company as the product is very good and the customer service is very good. We can conclude that employees have put their hearts and souls into a great product, service, and company. The employees radiate and feel it, the customers experience it, and the company benefits from all of it.

Yes, there are unhappy employees at companies that generate profits, but this will always be a short-term gain. If employees are not putting their hearts into their work, customer service will suffer, and innovation is repressed, killing any chance for the product to evolve and satisfy the customer's growing and changing needs. Change must come from the inside first, if change is to take place and morale of employees is to climb. This is true with all of us. Employees do not perform at their best when they are stressed, down and out, or feeling something wrong inside. Controlling how an employee feels is in direct correlation to how happy customers feel about their experience and whether they return to you or go to a competitor.

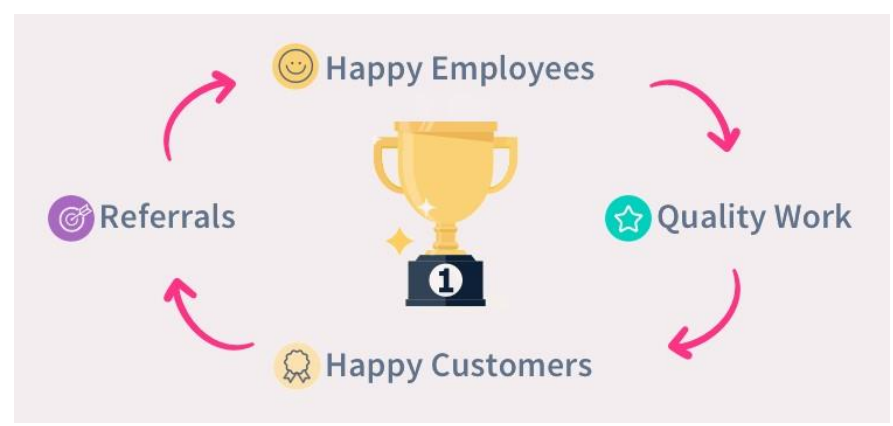

Figure 2: Happy Employees lead to happy customers

Customers are our lifeline. They pay the bills, salaries, and provide the resource needed for infrastructure, like expansion. Happy employees put their hearts into their work and produce innovative ideas, products, and services that benefit both 
customer and company. How the cycle of happy Employees resulting in happy Customers and vice-versa is illustrated in the above Figure2.

\section{OBJECTIVES AND METHODOLOGY}

Customer centricity in marketing has been talked about in many management forums, but the importance of employee involvement in the process of customer satisfaction through production ad dispatch of quality products to the specifications required needs to be highlighted particularly in the current environment of digital connectivity. Happy customers are created by happy employees. Organizations are becoming more and more aware of this connectivity not only through the physical layout but also through the emotional involvement. That customer satisfaction is achieved through committed employees through their involvement in quality and reliability of products and services offered, is being more and more understood by management of organizations. There is a need to understand this aspect in the current environment where digital connectivity and devices have proliferated. With these thoughts in mind following specific objectives have been identified for the purpose of this research paper:

1. A brief review of environment and relevance to current research.

2. Connectivity between Employee motivation and customer satisfaction.

3. How organizations are coping with this problem.

4. Challenges for organizations in this regard.

5. Findings, conclusions and recommendations.

While arriving at the methodology for the above research the objectives identified and the availability of information were considered while searching for suitable data. Environmental scans were available from the web pages and while searching for relevant information it was found that adequate research work could be down loaded from web pages. The main task was to classify the information and identify data which could be used for the research paper. The data search indicated availability of sufficient information which was compiled from various sources as referenced in the bibliographic section. Analysis and classification of data have been done with due diligence and the work completed. The conclusions and recommendations from the study are given.

\section{REVIEW OF LITERATURE}

A company is doing something right if both their employees and customers are happy. The importance of employee engagement and the consequent effect on customer satisfaction is being highlighted in this research paper. The important question is if there is a connection between the two, what the organizations are doing to improve or enhance customer satisfaction.

\section{HAPPY EMPLOYEES = HAPPY CUSTOMERS}

It is not just a speculation; these two elements really are deeply connected. Employee satisfaction is directly linked to customer satisfaction - and customer satisfaction is directly linked to financial performance. It's a winwin. While engaged employees lead to satisfied customers, the opposite is also true. Satisfied customers also play a role in employee engagement. Positive customer experiences can reinforce how employees feel about the value and purpose of their work and identify with company. It motivated them to repeat their behavior, to see even more value and purpose in their work. While it's important to learn from negative customer experiences, positive ones are to be highlighted to motivate employees and drive engagement. Therefore, managers and supervisors should highlight and recognize customer satisfaction success stories.

An example of a company which enjoys both happy customers and happy employees is Starbucks. This coffee maker has succeeded because of their superior customer and employee experiences. Customers want to feel appreciated when they interact with your business and so do your employees. Job security, fulfillment, and satisfaction are all ingredients that keep your turnover rate low and your customers happy. In the same way your employees need to feel the same as your biggest customer; they need to be happy and satisfied. One popular bumper sticker phrase, "A Smile is Contagious", is an appropriate way to explain the relationship between your employees and your customers.

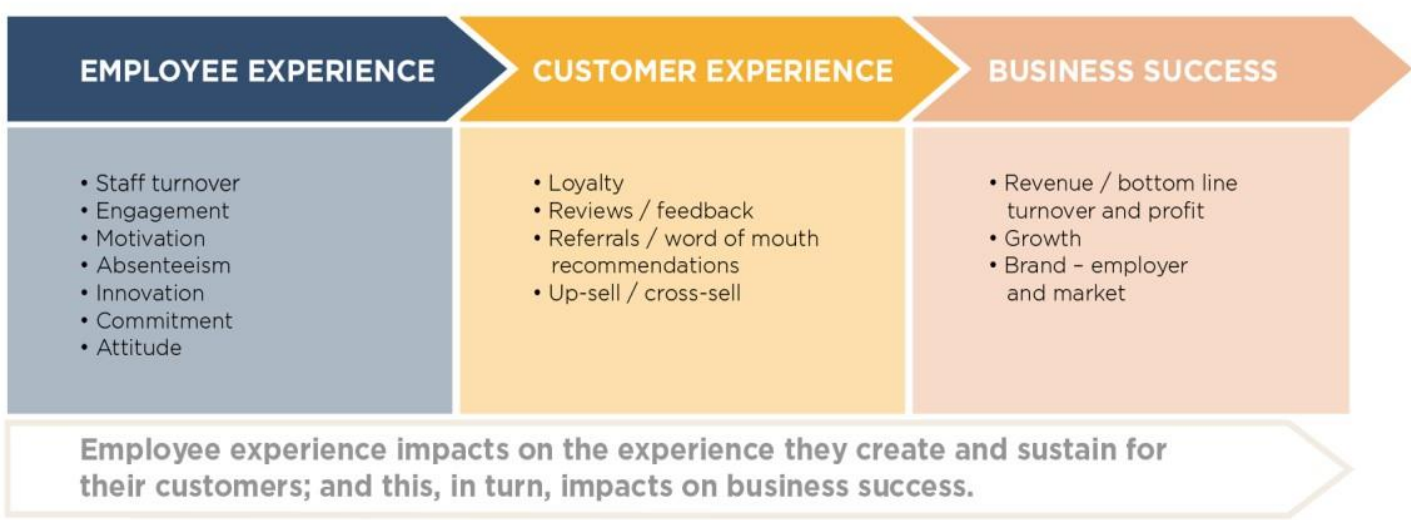

Figure 3: How Employee/customer experience impacts business 


\section{CUSTOMER ENGAGEMENT IN THE DIGITAL ERA}

Companies adopt various strategies to engage themselves with the customer and consumer and in the 'ALWAYS ON' digital age this is an essential element of strategy. Communication with the customer is an essential element and this has to be done on a continuous basis to understand his requirements. One of the key elements will be to get feedback on present products and ensure follow up and product modifications. A component of this feedback is to know the futuristic requirements for introducing new products before any competition can catch up. You need to keep the customer of the new product features and performance details and involve them in the development which would help the company in pricing strategy and convincing customer to share the development costs. These strategies will help customer retention and control any alienation before even the customer can think of, because you are developing the exact product for his requirement by involving him and making him share development costs if possible either upfront or with a spread over future orders (which incidentally may be a better strategy to keep the customer hooked).

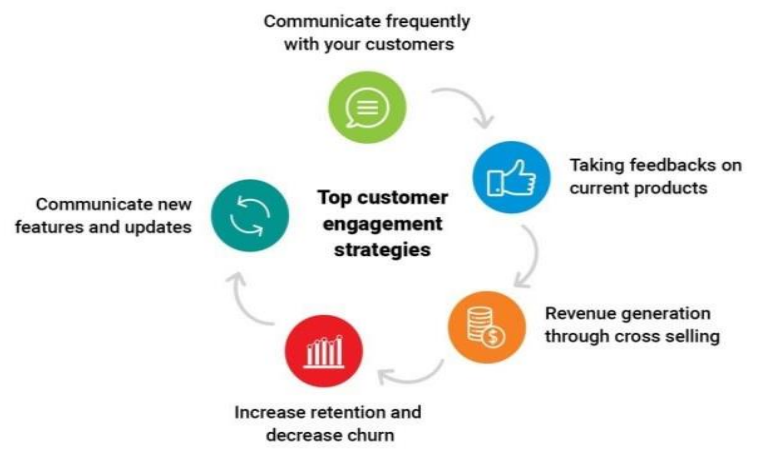

Figure 4: Illustrating customer engagement strategy

At any point of time revenue generation is your concern and avoid any crossselling of your own products. The relevance of social media in customer engagement needs no highlighting as it is the IN-THING for most companies. Figure 5, is an illustrative example of the era of customer engagement.

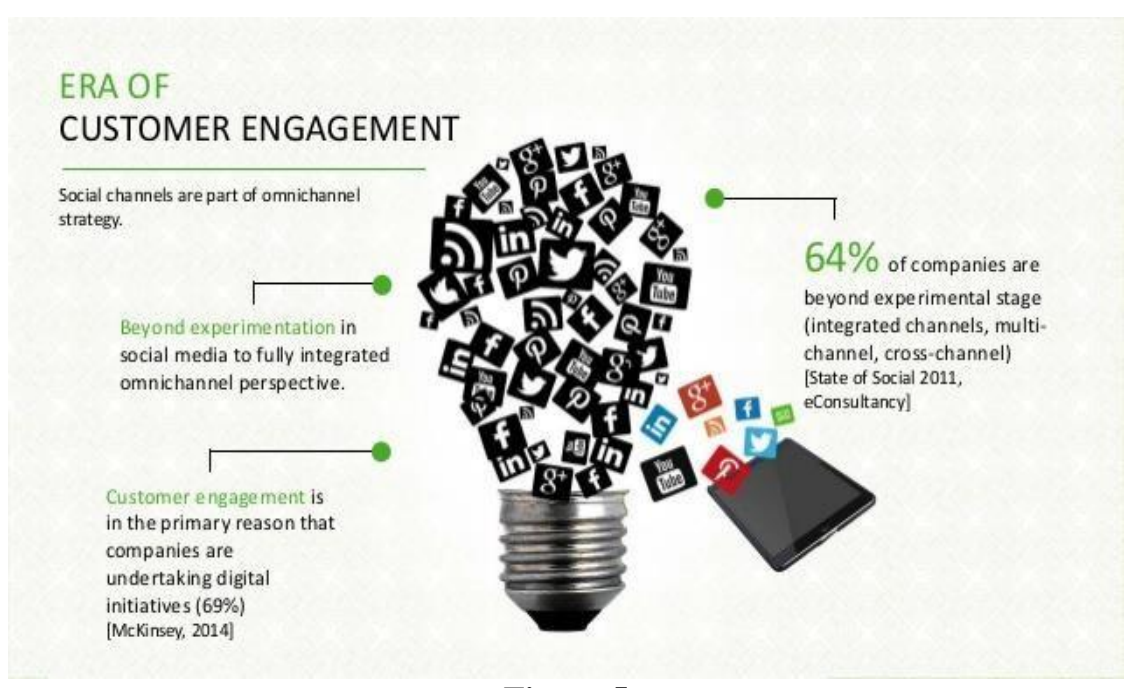

Figure 5

Social media is an important aspect of the channel strategy and is beyond experimentation and is fully integrated with omnichannel requirements. As of 2011 about $64 \%$ of companies were beyond the experimental stage. A McKinsey study in 2014 has indicated that the primary reason for customer engagement is that $69 \%$ of the companies are digitalized for customer engagement. Various companies have developed their own models for customer engagement in the digital age and one such model ' Multek customer engagement model' developed by Multek company is indicated below as figure 6. 


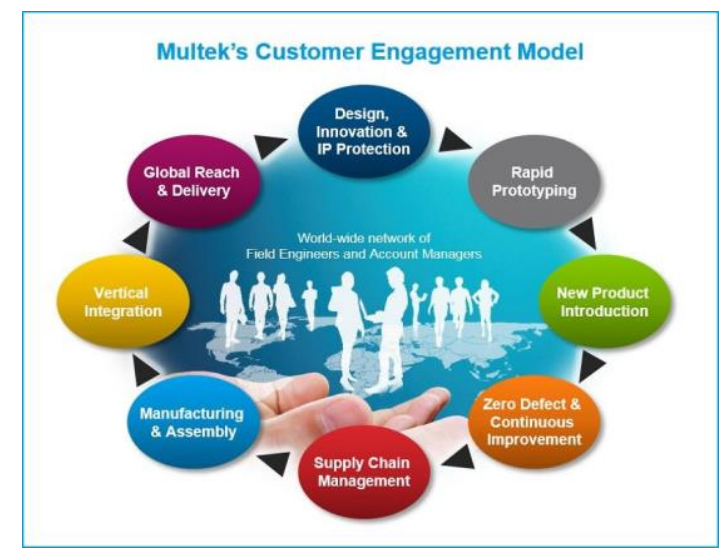

Figure 6

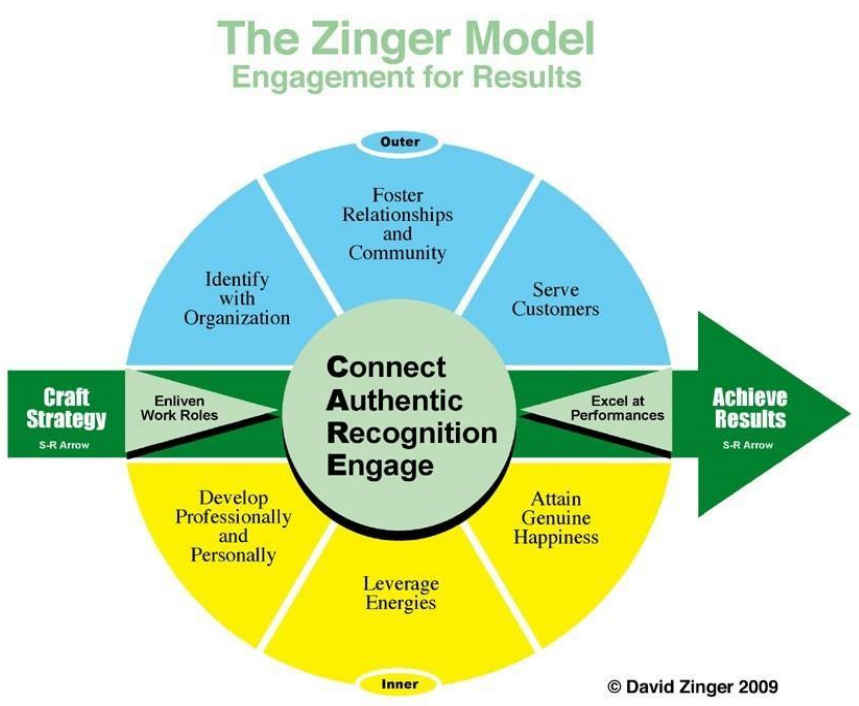

Figure 7: Customer engagement for results

Actually customer engagement on a continuous basis helps customer service. Companies on many occasions concentrate on improving their customer service skills on the way to improve customer engagement. Zinger model for customer engagement shows how customer happiness (customer delight) can be achieved through engagement. It shows the strategic importance of customer engagement and how employee commitment and involvement can be improved by customer orientation towards service and employee orientation and recognition. Gains from customer service and relationships are leveraged for achieving organizational goals of better employee relations and commitment. This model helps employees to improve their professional standing in the company and industry. That is how customer service helps in the long run to improve employee skills and genuine happiness.

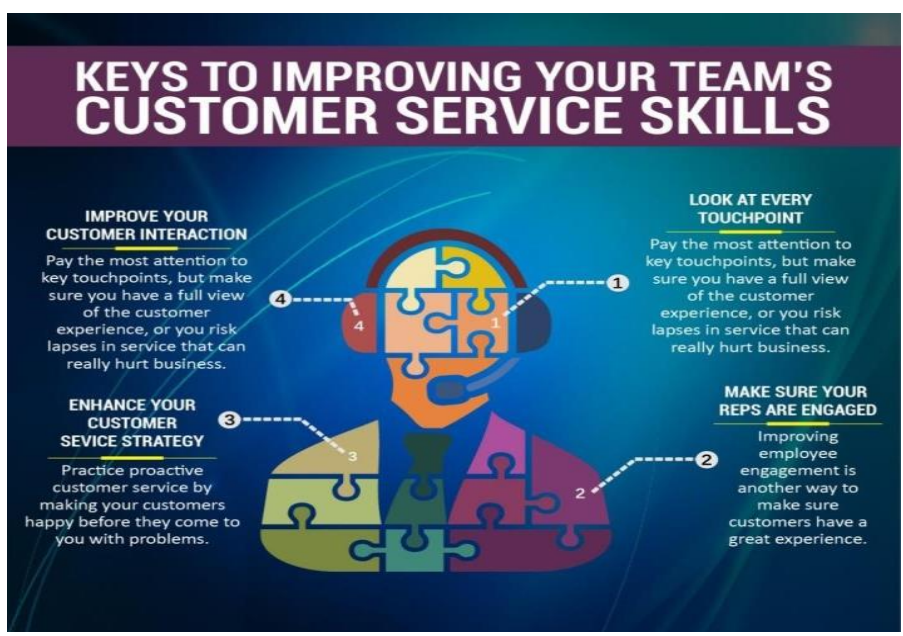

Figure 7: Keys to improve customer service.

Companies in their attempt to improve customer interaction and engagement actually improve customer service. By improving customer interaction and actively engaging with customers, your touch points with customer improves and 
paves the way for customer acceptance of your company, products and services. With the increase in competition among all industries, Customer service has become an essential part of a company. The biggest challenge in customer service is to deliver best quality products along with the best after sales service in a consistent way. This is the ultimate challenge that organizations face and addressing it becomes a very tedious task. There will be many permutations and combination of questions, feedback, and queries you have to face, but many service challenges are more common than the others. So, here is an insight on how to tackle tricky questions, take a look at the top 7 customer service challenges that you might have to face and the proper ways to resolve them.

A customer, in all sincerity, may ask a question that a sales executive may not know how to answer. However, this is where your team can guide that customer to the right place or try to get the information in order to pacify them. But most times you might not have the answer but you cannot shrug it off with a negative response. The logical thing would be to acknowledge the difficulty of the question and ask for some time and guarantee a call back with an appropriate answer. Consumers hate it when they have to listen to the popular automated message: 'Your call is important to us, please stay on the line while we transfer your call.' All your customers expect quick answers and fast responses, and they expect you to provide top quality support with the help of today's technology and gadgets. It is not the time to show how your company is using a new technology; it is all about providing the right support through it. You cannot hide behind the veil of technology which will show your team is incompetent. Also, whatever technology or system you introduce, you have to make certain that it is implemented across all departments so that all types of questions can be answered in a faster way, thus providing your customers with the effective support.

A customer can vent his or her anger for various reasons but it is your job to make sure that proper service and help is provided in order to find the right solution. Ignorance is not at all bliss here. Customer Service is a very tricky thing; you and your team may have to face these and several other challenges regularly. Solving them would provide your team with the confidence to tackle the next case, and it also will allow you to create a bond with the customers, and overall, build up your reputation in the market.

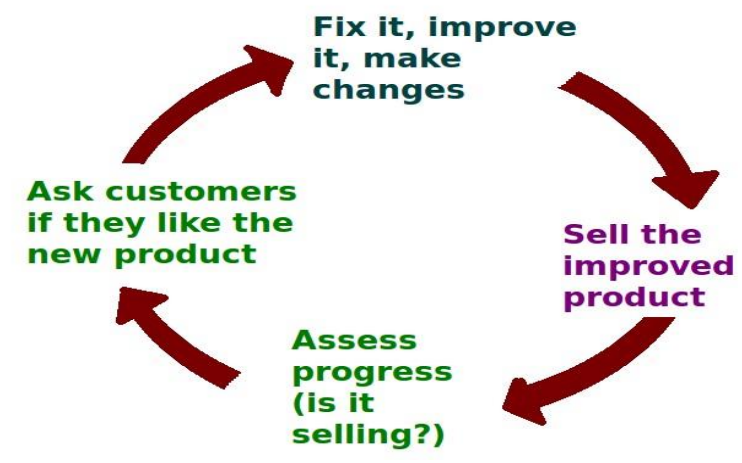

Figure 8: Customer service is not another quick fix

In this modern age, the company should have a customer-centric approach to survive and succeed in this competitive global market. Customer expectations constantly keep changing these days so the biggest challenge is to fulfill those expectations by keeping themselves one step ahead \& updated based on customer feedbacks on latest market trends. Doing continuous research and gathering data will help to serve customers in a much better way. There are various ways such as print media, television, telephone, and social media from where one can gather data about customers and as a result, this will help customer service representatives to deliver great services to customers. But the digital and always on media is more relevant today. Instituting a policy frame work and strictly following the policies by all the employees will help the difficulties of the customer service representatives to some extent. But every company wants to exceed customer expectations. Given below are some points which will help us to exceed Customer Expectations.

- Collecting Customer feedbacks and if the company starts working on those areas where they need improvement will help them to improve their brand image

- Proper and impactful training to your customer representatives \& empowering them will boost their confidence and they will happily boost the company's brand image and will be able to create an amazing experience for the customers.

- By focusing on small things and adding a personal touch with the customers will surely help to exceed customer's expectations beyond the limit.

Skilled and trained customer service executives are needed to handle angry customers in an emotional way. Angry customers only need someone to listen and consider their problem effectively. They need an emotional touch as they are suffering despite the fact that they are not at fault. Best way to handle them is apologizing sincerely. By apologizing and making them understand calmly that you are very sorry that the experience was not up to your expectations, but you are not to blame. It's tough to make the customer happy by providing a perfect solution but one must try to make the best effort in satisfying customer. 


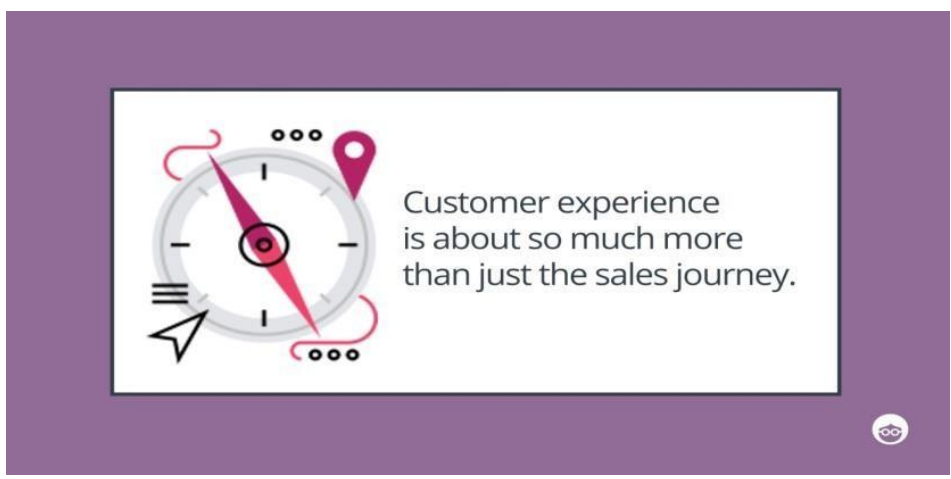

Figure 9: Food for thought

\section{DATA ANALYSIS AND CONCLUSIONS}

The current business environment is characterized by instant connectivity between Employer, employee and customer. Digital devices have become so common and they are increasing exponentially day by day. In such a connected environment the employees, who are also customers for several of their own company products being a consumer are well informed about the product capabilities and customer feedback on their field performance. Even if there is the least amount of non-congruence between expectations and performance, they come to know of it instantaneously. In the present digital age and connectivity, it does not take long to get the word across.

In this environment, the employee motivation depends on customer satisfaction and customer satisfaction is tied to motivated employees who produce the product and offer satisfactory services after sales. Since there is a perpetual connectivity between a customer and employee (sometimes both are on the same side), product acceptance depends on good performance. In the present environment the employee comes to know of it even before the official channels of communication through informal channels of communication. This is the moot point for consideration of manufacturers of all types of products, particularly consumer products.

Companies deal with this situation by having a strategic orientation to the real world. Providing excellent customer service along with customer engagement for a dialogue in which employees play a key role. Trained and skilled customer services executives provide the back up for products and the vigilant employees are always alert to any deviations I product performance and customer expectations. The employees are the brand ambassadors for the product and through experiential skills and continuous training are ready to meet customer challenges on a day to day basis. They do not allow grass to grow, and the speed of response to customer problems is ever accelerating and continuous. This is really the secret of success of many companies. The slower ones lose the race and market share.

It is not an easy situation for organizations whose resources are limited and have competing claims. Organizations are becoming more and more customer centric and focused through digital connectivity. While on the one hand organizations have to take good care of their customers, they cannot at the same time neglect their employees who make it possible to serve the markets and customers. This is a balancing act and is at the core of corporate strategy for any company. The first and foremost consideration that will be bothering a midsized organization is the allocation of scarce resources. While on the one hand improving customer service would mean more allocation of resources mainly money and manpower which will have equally competing claims in organizations from other departments like manufacturing, technology and quality. Resource allocation has to be very much focused on corporate strategy to improve customer satisfaction through Product improvements and new product development. Training and orienting the current employees can save cost of new recruitment and improve commitment. So, organizations need to consider various options to procure resources for the strategic initiatives which are an ongoing activity.

\section{SUGGESTIONS AND RECOMMENDATION}

Organizations have to refocus on key issues of which customer centricity in marketing, all departments dealing with customer satisfaction and employee motivation will have competing claims as far as resources are re-invested. But strategic initiatives have long term perspective of organization as a going concern have to carefully consider alternatives. The connectivity between their employees (who may be customers themselves) and customers is irrevocable and has a long term perspective. Motivated and committed employees are corporate resources which cannot be easily replaced. Organizations have to create policies for retaining and retraining such employees. Awhile the digital progress cannot be halted or slowed down, companies can train and recruit new employees who are savvy. There are, of course, no one size fit all solution which I presume all companies are aware!

\section{BIBLIOGRAPHY}

\section{A. PRINT \& PUBLICATIONS}

[1].N. Allen, D. Grisaffe, Employee commitment to the organization and customer reactions: Mapping the linkages, Human Resource Management Review, 11 (2001), pp. 209-236

[2].Bitner, Mary Jo, Bernard H. Booms, and Lois A. Mohr, "Views of Service Encounters by Customers and Employees," in progress. 
[3].Bitner, Mary Jo, Bernard H. Booms, and Mary Stanfield Tetreault (1990), 'The Service Encounter: Diagnosing Favorable and Unfavorable Incidents," Journal of Marketing, 54 (January), 71-84.

[4].E. Babakus, U. Yavas, O. Karatepe, T. Avci, (2003) The effect of management commitment to service quality on employees' affective and performance outcomes, Journal of the Academy of Marketing Science, 31, pp. 272-286

[5].L. Berry (1981), The employee as customer, Journal of Retail Banking, 3 (1981), pp. 25-28

[6].T. Bijmolt, P. Leeflang, F. Block, M. Eisenbeiss, B. Hardie, A. Lemmens,( 2010) et al., Analytics for customer engagement, Journal of Service Research, 13 (2010), pp. 341-356

[7].R. Bolton, (2011), Customer engagement: Opportunities and challenges for organizations, Journal of Service Research, 14 pp. 272-274

[8].J. Bowden, (2009), The process of customer engagement: A conceptual framework, Journal of Marketing Theory and Practice, 17 pp. 63-74

[9].S. Cadwaller, Ch. Burke-Jarvis, M. Bitner, A. Ostrom, (2010), Frontline employee motivation to participate in service innovation implementation, Journal of the Academy of Marketing Science, 38 pp. 219-239

[10]. J. Cambra, I. Melero, F. Sese, (2012), Customer engagement: An exploratory study in the mobile communications industry, Universia Business Review, 33 , pp. 84-103

[11]. Davis, Mark H. and H. Alan Oathout (1987), "Maintenance of Satisfaction in Romantic Relationships: Empathy and Relational Competence," Journal of Personality and Social Psychology, 53 (August), 397-410.

[12]. G. Druckenmiller, (2009),Customer engagement: Using technology to build relationships, Mintz \& Hoke Communications Group

[13]. W. George, (1990), Internal marketing and organizational behaviour: A partnership developing customer-conscious employee at every level, Journal of Business Research, 20 , pp. 63-70

[14]. E. Gummensson, (1987), The new marketing-developing long term interactive relationships, Long Range Planning, 20 pp. $10-20$

[15]. L. Hollebek, (2011), Exploring customer engagement: Definition and themes, Journal of Strategic Marketing, 19 pp. $555-573$

[16]. O. Karatepe, (2006), Customer complaints and organizational responses: The effects of complaintś perceptions of justice on satisfaction and loyalty, Hospitality Management, 25 , pp. 69-90

[17]. V. Kumar, L. Aksoy, B. Donkers, R. Venkatesan, T. Wiesel, S. Tillmans, (2010), Undervalued or overvalued customers: Capturing total customer engagement value,

Journal of Service Research, 13 , pp. 297-315

[18]. Karnes, Roger Eugene (12 August 2008). "A Change in Business Ethics: The Impact on Employer-Employee Relations". Journal of Business Ethics. 87 (2): 189-197.

[19]. J. López-Sánchez, C. González, L. Santos, (2010), Service innovation and customer co-creation: Effects on performance, Revista Española de Investigación en Marketing, 17 pp. 79-102

[20]. L. Mohr, M. Bitner, (1995), The role of employee effort in satisfaction with service transactions, Journal of Business Research, 32 pp. 239-252

[21]. A. Mollen, H. Wilson , (2010), Engagement, telepresence, and interactivity in online consumer experience: Reconciling scholastic and managerial perspectives Journal of Business Research, 63), pp. 919-925

[22]. Leong, Siew Meng, Paul S. Busch, and Deborah Roedder John (1989), "Knowledge Bases and Salesperson Effectiveness: A Script-Theoretic Analysis," Journal of Marketing Research, 26 (May), 164-178.

[23]. Parasuraman, A., Valarie A. Zeithaml, and Leonard L. Berry (1985), "A Conceptual Model of Service Quality and Its Implications for Future Research," Journal of Marketing, 49 (Fall), 41-50.

[24]. Smith, Ruth A. and Michael J. Houston (1983), "Script-Based Evaluations of Satisfaction With Services," in Emerging Perspectives on Services Marketing, eds. Leonard L. Berry, G. Lynn Shostack, and Gregory D. Upah, Chicago: American Marketing Association, 59-62.

[25]. J. Van Doorn, (2011), Customer engagement: Essence, dimensionality, and boundaries, Journal of Service Research, 14 ), pp. 280-282

[26]. J. Van Doorn, K. Lemon, V. Mittal, S. Nab, D. Pick, P. Pirner, (2010) et al. Customer engagement behavior: Theoretical foundations and research directions, Journal of Service Research, 13, pp. 253-266

[27]. P. Verhoef, W. Reinartz, M. Krafft, (2010), Customer engagement as a new perspective in customer management, Journal of Service Research, 13 pp. 247-252

[28]. S. Vivek, (2009), A scale of consumer engagement, (Doctor of philosophy dissertation), Department of Management and Marketing, Graduate School - The University of Alabama, UMI

[29]. F. Wangenheim, H. Evanschitzky, M. Wunderlich, (2007), Does the employee- customer satisfaction link hold for all employee groups?, Journal of Business Research, 60 pp. 690-697

[30]. S. Wigley, B. Lewis, (2012), Rule of engagement: Practice what you tweet Public Relations Review, 38 pp. $165-$ 167

[31]. Webster, Frederick E., Jr. (1988), "The Rediscovery of the Marketing Concept," Business Horizons, 31 (May-June), 29-39.

[32]. X. Zhang, K. Bartol, (2010), Linking empowering leadership and employee creativity: The influence of psychological empowerment, intrinsic motivation and creative process engagement, Academy of Management Journal, 53 pp. 107-128

[33]. Zeithaml, Valarie A., Leonard L. Berry, and A. Parasuraman (1988), "Communication and Control Processes in the Delivery of Service Quality," Journal of Marketing, 52 (April), 35-4 